\title{
Maritime Migrations: Stewards of the African Grove
}

\author{
ANITA GONZALEZ
}

This essay discusses how maritime migrations contribute to movements of ideas across transnational ethnic communities. It focuses on actors from the African Grove, a New York City-based African American theatre company. Actors in this company worked as stewards on transatlantic packet ships where the architecture of the ship supported intercultural exchanges.

The maritime world - the world of ships and ports and landings - is a distinct cultural arena where relationships are made and hierarchies persist. The lifestyle of the mariner, intrinsically migratory, supports travellers and labourers who encounter one another in a liminal space. Within this liminal space, paradigms of race and gender are reimagined and cultural relationships negotiated. Prior to the 1950s, when air travel became predominant, maritime highways were the primary way in which global populations migrated and experienced the world. While humanities scholars tend to focus on ports and land-based economic and social systems, first encounters of races and cultures - particularly during the nineteenth century - happened within maritime spaces.

I am writing a book called Shipping Out which analyses maritime performance. The project investigates how performances on ships and in maritime ports enable cultural encounters and dialogic exchange. I aggregate my discussion of maritime performative interactions around five areas: 'The Backdrop of the Ship', 'Play at Sea', 'Theatrical Ports', 'Spectacles of Cruising' and 'Sea Refugees and the Theatrics of Escape'. Woven throughout each chapter are discussions of race, gender, power, hierarchy and, of course, performance. Central to my writing is an interest in performance as a mechanism for working-class communities to articulate identities and comment upon their economic and social status. My project brings dance methodologies, coupled with analysis of visual materials, to a nineteenth-century maritime archive which consists of architectural ship plans, lithographs, paintings of port performers, sea shanty lyrics and descriptions of unusual festivals or parades.

\section{The case of the steward}

Nearly half a century ago - in 1816-17, to wit - there sailed from the port of New York, in one of the Liverpool packets, as steward thereof, a tall black man named Brown. He belonged to the class which, at that time, and for years afterwards, even to the present day, occupied a respectable and responsible position. The steward was then, next to the 
captain, the most important personage on the ship. Dressed in his brilliant-coloured morning-gown and red slippers, he was wont to receive passengers with 'stately courtesy', which was duly reciprocated by those who went down to the sea in ships. ${ }^{1}$

This passage, from the January 1860 issue of the Anglo African, describes a coloured freeman named William Brown, who founded the first professional African American theatre company, the African Grove, in New York in $1821 .^{2}$ William Brown was a retired ship steward and his main actor, James Hewlett, worked as a tailor and a steward on the Liverpool packet ships (vessels which transported mail and passengers between New York and Liverpool in the UK). Brown likely relocated from the Caribbean, sailing up the Gulf Stream to settle in New York, where a community of free African American and Caribbean domestic workers supported his entertainment garden. Discussion of the African Grove highlights how maritime migrations contributed to the movement of ideas across transnational ethnic communities. Actors in this company, which operated during the height of slavery, performed works by Shakespeare, Pizarro and other European playwrights, as well as new work about Caribbean politics. Their original play King Shotaway described a revolution on St Vincent island led by indigenous leader Joseph Chatoyer. Through their performance repertory, they celebrated the nobility and diversity of African American experiences. I maintain that their employment on packet vessels exposed them to new ideas, enabling these workers to export notions of freedom and theatrics across class and national boundaries. ${ }^{3}$ The merchant ship was the transitory home of these nineteenth-century actor/workers and their activities contradict narratives of the ship as a place of violence and enslavement.

Sailing while black was undoubtedly fraught during the nineteenth century; tensions between freedom and slavery were troubled. Marcus Rediker's The Slave Ship and the newer volume Slavery at Sea by Sowande Muskateem describe in brutal detail how terror, sex and sickness proliferated on nineteenth-century slavers. ${ }^{4}$ Enslaved women were forced to fulfil the carnal desires of sexually deprived sailors, while acts of mutilation deliberately designed to terrify the captives were regularly inflicted on the human cargo. While slave ships represent an enduring horrific middle passage for African Americans, they were not the only vessels transporting Africans. People of African descent travelled in vessels of many types during the nineteenth century. Some of them were free black actors.

In some ways, the materiality of the ship allowed for shifting human interactions. If we imagine the maritime circuit of a slave vessel travelling a round trip from England, we can see the intimate relationship between cargo, vessel and load. A sailing ship, loaded with firearms and crew, might travel to Ghana, where it offloads weapons and trades them for human cargo, who rebalance the ship. The ship crosses the Atlantic Ocean to the Caribbean, where enslaved Africans are offloaded and traded for rum and sugar, cotton or tobacco. The ship is rebalanced and these goods are perhaps transported to New York harbour, where some of them may be exchanged for lumber, which is much-needed to build homes in England. Lumber and cotton bales are readjusted, then transported to England, where there are redesigned into clothing 
and buildings, or perhaps more wooden ships. In a similar way, intellectual and artistic ideas travelled and shifted as they crossed international boundaries.

Migrating workers, whether free or enslaved, interacted with the architecture of the ship. Because the ship was home, worksite and transport, it required workers to spend long hours at specific locations. Occupation determined where workers spent the majority of their time in the ship and with whom they interacted. In this section, I walk the reader through a ground plan of the packet ship, the work place of actors of the African Grove. Although they were contained within the vessel, their service, coupled with the vessel's architecture, gave them access to the captain's intellectual exchanges.

Packet ships were originally organized within the British Isles to connect mail services across the islands; they were common throughout the eighteenth century. By 1702 there were services in Barbados, Jamaica, Florida, California, Charleston and Pensacola. In 1755, service to New York City was added, weather permitting. One of the first packet lines to sail between New York and Liverpool was the Black Ball line. ${ }^{5}$ Founded in 1817 in the United States, the shipping line outrageously proposed to have regular sailings on schedule between North America and the British Isles. To prove their point, they launched in January, subjecting their workers (later known as 'packet rats') to the harsh realities of sailing North Atlantic waters during the winter season. By 1820, the time of the African Grove, there were multiple shipping lines offering regular service between the East Coast of the Unites States and the United Kingdom. An 1823 advertisement from the Evening Post describes packets offering 'extensive and commodious' accommodations for the price of thirty guineas (see Fig. 1). Stewards, sometimes of African descent, would service these accommodations, working in close proximity to passengers and the crew.

Packet ships provided tight quarters for a journey which could take two or three weeks. They were basically cargo ships adapted for passengers. A detailed representation of the deck plan for the packet ship Rousseau (see Fig. 2) shows a vessel weighing 305 tons. ${ }^{6}$ The captain's quarters adjoin the berths of the mates, with the upper-class passengers housed in similar berths nearby. Mates (privileged workers on the ship) would have access to the captain's dining table, a private exit to the deck, and bathrooms. Immigrants and second-class passengers were housed midships on interior decks, with separate stairway access to the upper decks. The lowest deck is reserved for cargo, which includes food for the guests. Common crew quarters are located at the front of the ship, where waves would hit the hardest, but some ship plans locate steward's quarters adjacent to the captain and his mates. Both the cook and the steward, while occupying the most menial positions, would come into contact with privileged conversations because of the architecture of the ship.

Positions of steward and cook were frequently occupied by men of colour. In the South Pacific, South East Asian men tended to work as cooks, and in Atlantic waters African or Irish men held these jobs. Both positions required complex negotiations of ship politics. A Nautical Cookery Book published in 1896 by Thomas Francis Adkins provides extensive details about the life of a cook. ${ }^{7}$ It was difficult to keep stock fresh and crew members regularly complained of bad food. Cooks needed to know how to care for livestock, prepare devilled bones and use saltwater to make bread. Other 


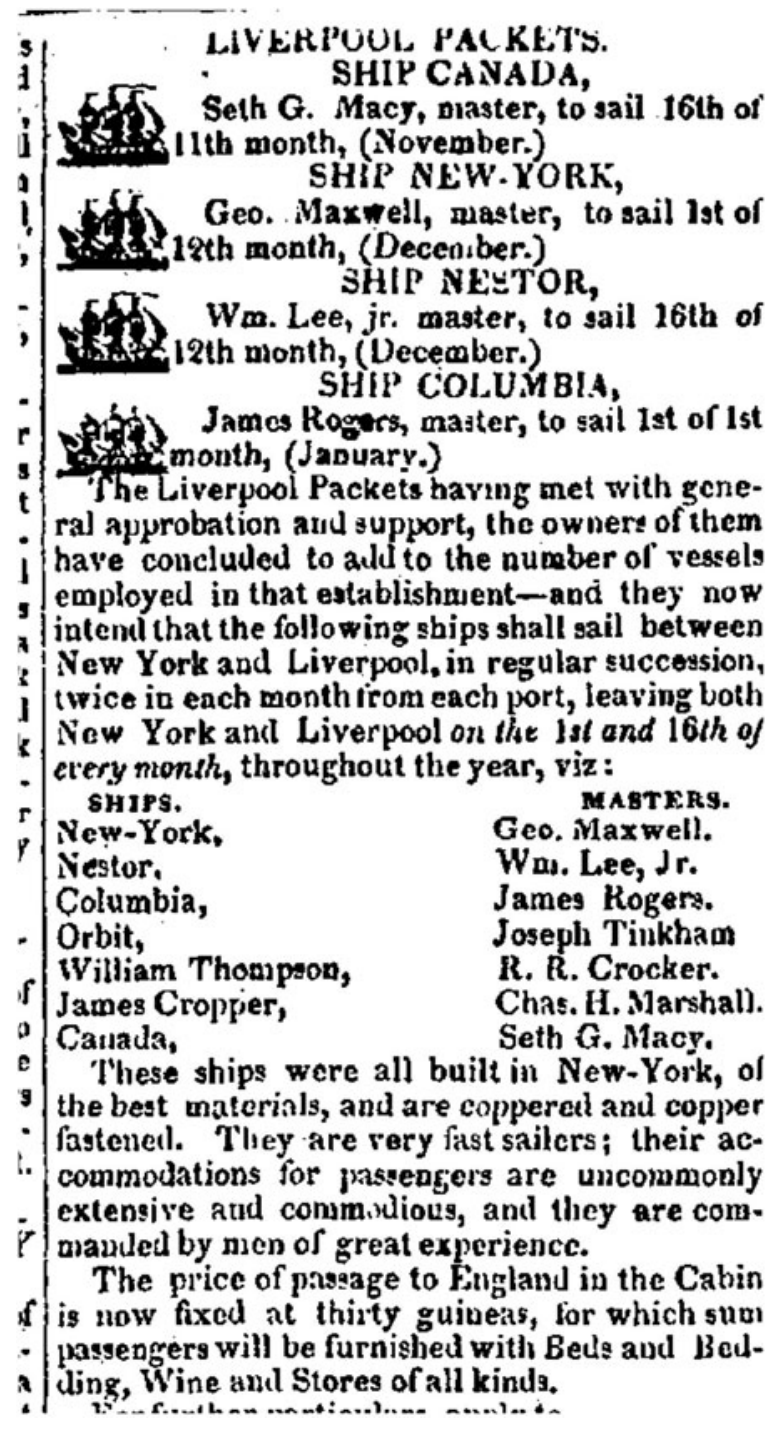

FIG. 1 Advertisement for passengers to sail on Liverpool packet ships from the Evening Post, 1 December 1823, Issue 6665, New York, courtesy of American Antiquarian Society (20140). The packet ships offered mobility and employment for free African American and Caribbean men during the first half of the nineteenth century. (c) Mystic Seaport Museum, Daniel S. Gregory Ships Plans Library.

records document the activities of the steward. He was generally responsible for feeding and dressing the captain, mates and passengers. The earlier description of the steward referencing a brilliant-coloured morning-gown and red slippers probably romanticizes the role. Michael Sokolow, author of Charles Benson: Mariner of Color in the Age of Sail, describes the more puritanical life of a New England-based African American steward. ${ }^{8}$ Benson was a career mariner who kept a journal and sailed for over two 


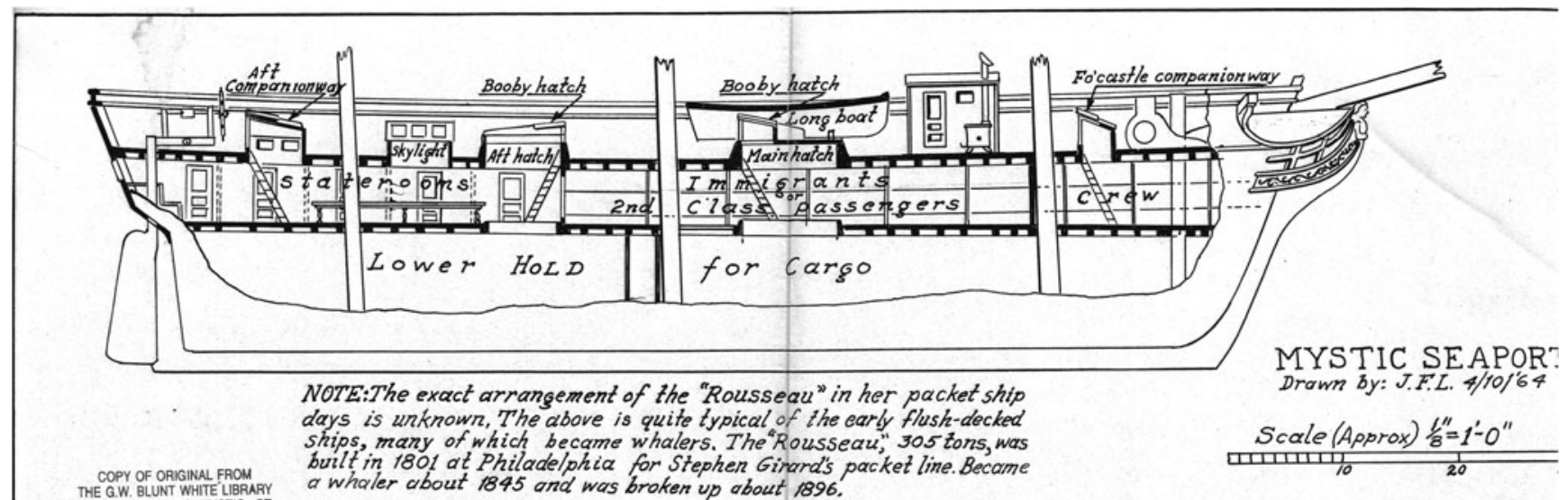

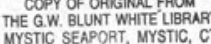
PERMISSON AEOUIED FOR REPBOOUCTION

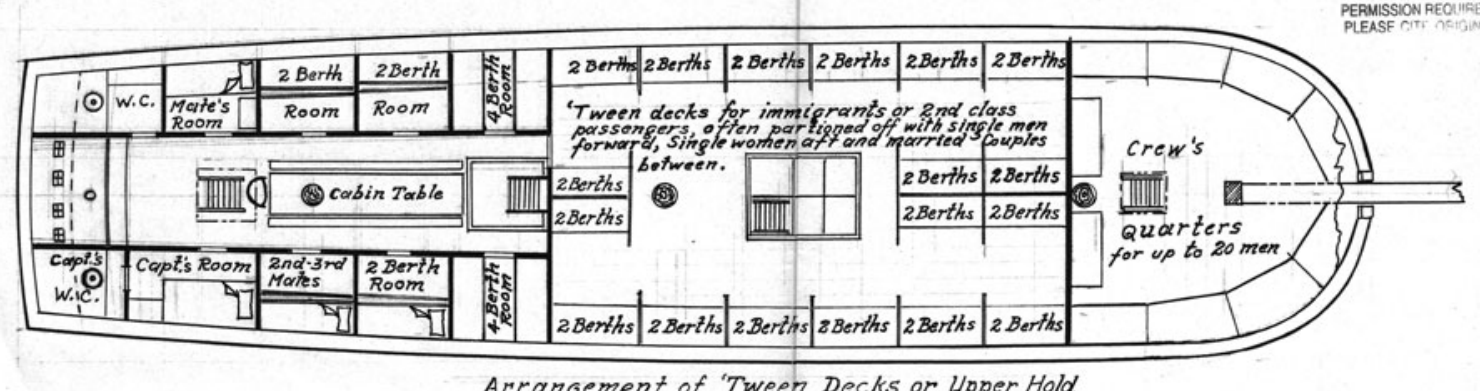

Arrangement of 'Tween Decks or Lpper Hold

\subsection{5}

FIG. 2 Ground plan of the packet ship Rousseau, built in 1801 and providing service until 1896. Ships like this carried free black men who worked as stewards servicing passengers and crew. The stewards moved freely throughout the vessels and carried knowledge from port to port. Some founded a theatre in New York City in 1821 called the African Grove. Courtesy of the American Antiquarian Society. 
decades to Zanzibar and Madagascar. His travel writings, compiled by Sokolow, reflect the life of a man respected by his captain and entrusted with responsibility for managing trade goods on ships and in ports. While Benson began his life as part of a small African American community in Framingham, Massachusetts, he gradually distanced himself from his town, his family, his community, and particularly the racial politics of the century. Unlike the African Grove players, he never settled.

Between 1818 and 1825 , being a steward was respectable employment for an African American free man in the North. Newspapers of the time show advertisements for coloured seamen requesting specialized skills. For example, an advertisement in the 1820 New York Daily reads, 'two likely colored men wanted as waiters on board the steamship Fulton - those who speak good French and Spanish will be preferred. Apply to the steward on board at the end of Cherry Street'. implies that free, black, multilingual stewards were both literate and available for hire. Although work was hard and journeys were unpredictable, working at sea enabled free black men to acquire income and travel with a polyglot crew to ports which varied considerably. Some ports, like those in the Caribbean, were multinational and multilingual, with active social lives. For example, an 1800 New Orleans port would have been a bustling, safe French province. After the Louisiana Purchase, however, English-speaking slavers would threaten black lives. Enslaved blacks would sometimes take advantage of variable port environments to escape.

One of the most renowned maritime refugees is Frederick Douglass, who escaped from the shipyards of Baltimore using borrowed papers from a free African American seaman. Douglas wrote, 'I had one friend - a sailor - who owned a sailor's protection, which answered somewhat the purpose of free papers. ${ }^{10}$ The narrative of Douglass's escape demonstrates how working at sea offered men of colour an opportunity for freedom within a liminal space. As political and social systems shifted, coloured sailors were able to literally navigate themselves away from one port and into more favourable territory. Sailing - migrating - while black in the nineteenth century meant negotiating a racial construct that was fluid and relative. Black in one port was brown in another, coloured in another, and so on. Not all black men were property, and white men were sometimes treated as harshly as the enslaved. It is no wonder, then, that free African American seamen would, whenever possible, gather in a safe space to entertain themselves with theatre and celebrate their mobility.

Unfortunately, the occupational status of stewards changed drastically between 1818 and 1850. By the end of the century, papers of the 'Colored Seaman's Boarding Home' indicate that most black seamen were impoverished. ${ }^{11}$ While we have no other records of entertainment gardens in New York, we know that the African Grove folded in 1827 , because of a smallpox epidemic, coupled with increasing animosity towards the African American company. However, it is clear that during a brief time within the nineteenth century, between 1820 and 1850, African American seamen were able to use their employment as stewards on packet ships to learn about entertainment and cultural traditions in Liverpool, London, Jamaica and the island of St Vincent, then use their knowledge to establish a vibrant theatre company in New York. Maritime space offered an opportunity for physical migration which 
placed particular types of workers in close proximity to an international flow of ideas. Discussion of the African Grove highlights how maritime travel contributed to the movement of ideas across ethnic communities. It also reveals how African Americans in particular used the maritime space to complicate notions of race, nationality and identity.

NOTES

$1 \quad$ James McCune Smith, 'Ira Aldridge', Anglo African Magazine, 2, 1 (January 1860), p. 29. Thomas Hamilton of Beekman Street in New York published a sketch about Aldridge in his magazine, 'devoted to the history, condition and culture of the Colored Population of the United States, free and enslaved'.

2 Anglo African, 2, 3 (March 1860), back cover.

3 Marvin McAllister, White People Do Not Know How to Behave at Entertainments Designed for Ladies and Gentlemen of Color (Durham: University of North Carolina Press, 2003), contains the most comprehensive analysis of the African Grove.

4 Marcus Rediker, The Slave Ship: A Human History (New York: Penguin, 2007); Sowande Muskateem, Slavery at Sea: Terror, Sex and Sickness in the Middle Passage (Urbana: University of Illinois Press, 2016).

$5 \quad$ The Black Ball line initially consisted of four vessels: the Amity, Courier, Pacific and James Monroe. However the success of the industry grew quickly.

6 Original at G.W. Blunt White Library, Mystic Seaport, Mystic, Connecticut: The Log - January 1961. This vessel was built in 1801 in Philadelphia for Stephen Girard's packet line. It became a whaler about 1845 and was broken up about 1896.

7 Thomas Francis Adkins, The Nautical Cookbook: Alphabetical Guide to Sailor's Cookery for the Use of Stewards and Cooks on Cargo-Carrying Vessels (East Ham: Wilson and Whitworth Limited, Steam Printers, High Street North, 1899). The inside first page reads, 'Silver Medalist, Universal Food and Cooking Exhibition, 1896. Instructor of Nautical Cookery under the Technical Education Board L.C.C. at The Sailors Home, Well Street and Dock Street, London E'. Accessed at Greenwich Maritime Archives, August 2017.

8 Michael Sokolow, Charles Benson: Mariner of Color in the Age of Sail (Amherst: University of Massachusetts Press, 2003).

9 New York Daily Advertiser, 993 (14 April 1820), p. 2. Accessed at the American Antiquarian Society, 2014.

10 Frederick Douglass, Life and Times of Frederick Douglass (Hartford, CT: Park Publishing Co., 1881), p. 246.

11 The Colored Freemen's Home, managed by William Powell in New York, provided housing for homeless seamen seeking shelter. Papers from the home archived at the G.W. Blunt White Library, Mystic Seaport, Mystic, Connecticut show an increasing number of impoverished black sailors coming to the home as the century progressed.

ANITA GONZALEZ's (amanjo@umich.edu) most recent book is a co-edited anthology with Tommy DeFrantz, Black Performance Theory (2014), which theorizes black performance in the new millennium. Her monograph Afro-Mexico: Dancing between Myth and Reality (2010) is the result of a 2007 postdoctoral research fellowship in 'Race, Politics, and Performance' at the John L. Warfield Center for African and African American Studies (University of Texas at Austin). Other publications include articles about intersections between theatre and dance ('Negotiating Theatrics: Dialogues of the Working Man', The Oxford Handbook of Dance and Theater, 2015), maritime culture ('Megaship Economies and Transnational Maritime Performance', Theatre Research International, 2014), utopia in urban Bush Women performance (Modern Drama, 2004), archetypes of African identity in Central America ('Mambo and the Maya', Dance Research Journal, 2004), and the pedagogy of teaching African American drama (Theatre Topics, 2009). 